\title{
O Cinema-EnSAIO COMO FORMA NO DOCUMENTÁRIO CAPITALISMO: UMA HISTÓRIA DE AMOR
}

\section{Cristiane Toledo Maria}

Desde o início de sua carreira em 1989, com Roger e eu (Roger \& Me, EUA), até suas produções mais atuais, o cineasta norte-americano Michael Moore tem sido considerado um dos mais famosos documentaristas do mundo. Juntamente com sua fama e sucesso de bilheteria internacional, seus filmes trazem com frequência o debate acerca da definição do gênero documentário, bem como opiniões controversas ligadas ao debate sobre a ética, a manipulação e a relação entre cinema e propaganda política. Tais polêmicas na recepção da obra de Moore são fruto não apenas dos temas e teses de seus filmes, mas principalmente de seu estilo. Nesse contexto, uma investigação dos procedimentos formais presentes em sua obra se faz necessária para que possamos compreender o papel do cineasta dentro da tradição da arte política.

Escolhemos para esta investigação o filme Capitalismo: uma história de amor (Capitalism: A Love Story, EUA, 2009). Uma de suas últimas produções cinematográficas, esse documentário tem como proposta inicial tratar das causas e consequências da crise financeira que abalou os Estados Unidos e o mundo em 2008. Porém, o filme amplia sua área de análise, funcionando como uma espécie de síntese da obra de Michael Moore. Temas centrais de seus outros documentários, como o poder das corporações, a cultura do medo, o atentado de 11 de setembro, as demissões em massa, o papel da mídia e a administração do governo Bush são retomados durante o percurso da análise do cineasta para 
entender seu momento histórico. Além disso, muitos dos procedimentos estéticos desenvolvidos por Moore em seus outros filmes aparecem de maneira consistente e autorreflexiva nessa produção mais recente. Em linhas gerais, Capitalismo: uma história de amor sintetiza um processo de investigação, tanto em sua temática quanto em sua linguagem. E é nesse processo que ele se assemelha ao que chamaremos de "filme-ensaio", que será o foco desta investigação sobre o filme.

Nossa primeira pista é a sinopse escrita pelo próprio cineasta na ocasião da estreia de seu filme nas salas de cinema dos Estados Unidos:

Esse filme é uma história de crime. Mas é também uma história de guerra, sobre a luta de classes. E um filme de vampiro, com o $1 \%$ de cima se alimentando do restante de nós. E, claro, é também uma história de amor; mas de uma relação doentia. Não é sobre um indivíduo, como Roger Smith, ou uma corporação, ou um problema como o sistema de saúde. É o pacote completo. É sobre a coisa que domina todas as nossas vidas - a economia. Eu fiz esse filme como se fosse o último que me permitiram fazer. É uma comédia (MOORE, 2009, [s.p.]). ${ }^{1}$

Além de apontar para a mistura de gêneros, impossibilitando sua classificação dentro de uma categoria fechada, o fato de o termo “documentário" não ser mencionado já nos alerta para o uso de uma linguagem narrativa muito mais próxima aos elementos comumente encontrados no cinema dito "de ficção". Tal hibridez, que é uma das características do filme-ensaio, pode ser notada em diversos momentos do filme, mas a mais sugestiva de todas as menções da sinopse nos parece ser a "história de crime", justamente porque a narrativa detetivesca funciona como um espelhamento do caráter investigativo da linguagem ensaística. É por ela que iniciaremos nossa observação de Capitalismo: uma história de amor.

Apesar do título sugestivo, o filme não parte dos "ismos" para entender as relações econômicas, como a maioria das análises políticas o faz. A palavra "capitalismo" aparece poucas vezes no filme, e termos como "comunismo" e "socialismo" também são evitados ao máximo. Em vez disso, o diretor parte de exemplos concretos das relações entre o

\footnotetext{
1 "It's a crime story. But it's also a war story about class warfare. And a vampire movie, with the upper 1 percent feeding off the rest of us. And, of course, it's also a love story. Only it's about an abusive relationship. It's not about an individual, like Roger Smith, or a corporation, or even an issue, like health care. This is the big enchilada. This is about the thing that dominates all our lives - the economy. I made this movie as if it was going to be the last movie I was allowed to make." Todas as traduções de citações em língua inglesa são nossas.
} 
Capital e o dia a dia da população, revelando atrocidades que são feitas em nome do lucro empresarial.

"Por trás de toda grande fortuna, existe um grande crime". ${ }^{2}$ Essa referência famosa atribuída à obra de Balzac poderia resumir a tese do filme de Michael Moore, que a deixa explícita em determinados momentos, como, por exemplo, ao mostrar um casal de idosos sendo despejado de sua casa e se dirigir aos espectadores em voz-over:3 "o que vocês estão testemunhando é um roubo" (CAPITALISMO, 2010). ${ }^{4}$

Nessa frase de Moore existem elementos importantes para entender a função que os elementos da narrativa detetivesca possuem no desenvolvimento da tese do filme. O conceito de "roubo", por exemplo, começa a ser discutido desde as imagens de abertura do filme, nas quais vemos materiais de arquivo de câmeras de vigilância que capturaram diversos assaltos a bancos. Imediatamente a frase famosa de Brecht nos vem à mente: "O que é assaltar um banco, comparado com a fundação de um banco?". 5 No decorrer do filme, somos expostos a histórias horripilantes que revelam uma necessidade de repensar conceitos como "crime", "moral", "ética” e "justiça”, como o depoimento do dono da imobiliária Condo Vultures, que se orgulha de lucrar com a crise imobiliária norte-americana, o presídio para menores de idade - que se mostrou um negócio milionário, mais do que um serviço público -, e o Dead Peasants Insurance, seguro de vida que as empresas fazem para seus funcionários a fim de lucrarem

\footnotetext{
${ }^{2}$ Balzac não escreveu nenhuma frase exatamente com essas palavras. O mais próximo disso é uma citação encontrada em O pai Goriot (1835): "Le secret des grandes fortunes sans cause apparente est un crime oublié, parce qu'il a été proprement fait” [O segredo das grandes fortunas sem causa é um crime esquecido, porque foi feito corretamente.]. No entanto, há uma tese implícita nessa associação entre dinheiro e crime que é recorrente em seus escritos da A comédia humana.

3 Recurso frequentemente utilizado em documentários no qual a voz do narrador descreve os fatos de fora da cena. É uma espécie de narrador onisciente.

${ }^{4}$ As transcrições de trechos do filme foram retiradas da legenda do DVD distribuído pela Paramount Pictures Brasil

${ }^{5}$ Essa frase aparece na peça $A$ ópera de três vinténs, produzida em 1928. O personagem Macheath, antes de ser enforcado como punição por ser um criminoso, diz em seu discurso final: "É, então não vamos deixar as pessoas esperando. Minhas senhoras, meus senhores, estão vendo extinguir-se o representante de uma classe em extinção. Nós, os pequenos artesãos burgueses, que trabalhamos com o bom e velho pé-de-cabra as modestas caixas dos pequenos comerciantes, estamos sendo engolidos pelos grandes empresários, atrás dos quais estão os bancos. O que é uma gazua comparada a uma ação ao portador? O que é um assalto a um banco comparado à fundação de um banco? O que é o assassinato de um homem comparado com a contratação de um homem?" (BRECHT, 1991, pp. 103-104).
} 
com a eventual morte deles. Todos esses exemplos apenas reforçam a tese principal, de que as medidas políticas e econômicas das últimas décadas - desde o incentivo do governo norte-americano ao capital financeiro desregulamentado até o pacote de ajuda financeira dado aos grandes bancos e corporações para conter os danos da crise de 2008 - são também crimes cujas vítimas são a grande maioria da população do país.

Outro conceito-chave que aparece na supracitada frase de Moore é o de "testemunha". Testemunhar é ao mesmo tempo presenciar e se tornar de certa forma responsável pelo ocorrido, uma vez que a testemunha funciona como elemento essencial para a resolução do crime, ao relatar sua perspectiva dos acontecimentos. Se o cineasta coloca os espectadores na posição de testemunhas do "crime", espera-se que eles não apenas observem objetivamente os fatos, mas que sejam capazes de identificar os culpados e as vítimas, não se isentando do acontecimento. Afinal, a testemunha carrega a experiência da vítima indiretamente, colaborando para a investigação. No filme de Moore, tanto as vítimas quanto os cúmplices do crime servem como testemunhas, e trazem evidências importantes para a investigação.

Além disso, existe outro agente na investigação, capaz de recolher as perspectivas fragmentadas dos testemunhos e analisá-las em sua totalidade para entender o processo: o detetive, que no filme é representado por Moore - ora como personagem, ora como narrador, e até mesmo como autor-implícito. Tal postura pode ser observada na própria organização fílmica da narrativa, uma vez que, em certos momentos de denúncia, a câmera se posiciona como um detetive que recolheu as provas e as apresenta num tribunal. Em determinadas cenas, a câmera utiliza recursos técnicos de lentidão e aproximação, criando uma sensação de interação direta entre o diretor e o objeto filmado. Um exemplo disso é a sequência na qual o filme discute a aliança entre políticos e altos executivos de bancos de investimento e outras corporações durante a crise financeira. Bill Black, especialista em crimes de colarinho branco, entrevistado por Moore, comenta em voz-over sobre o fato de Henry Paulson (ex-presidente do banco Goldman Sachs e secretário do Tesouro durante a crise financeira de 2008) ter convidado executivos do banco para darem conselhos sobre a solução para a crise financeira. Nesse instante, a imagem que vemos é a de uma fotografia na qual estão o secretário Henry Paulson e alguns executivos do banco conversando numa sala de estar. $\mathrm{O}$ interessante dessa fotografia é que 
ela foi tirada através de uma janela, à distância, como por um grupo de paparazzi. O que a câmera de Moore faz, após a exibição da foto, é aproximar-se da fotografia com o zoom, dando-nos a impressão de que a câmera está ali naquele momento.

Assim, "o que vemos é o que podemos ver apenas quando a câmera, ou o cineasta, está lá em nosso lugar" (NICHOLS, 2005, p. 155). Temos a sensação de que, ao contrário da fotografia utilizada como material de arquivo, a câmera do filme se aproxima da janela para observar mais de perto, como se estivesse espiando e ouvindo a conversa, interagindo com aquele conteúdo de corrupção, para poder revelar depois aos espectadores as informações às quais teve acesso - no caso, que houve um acordo entre as duas partes para que o dinheiro dos impostos da população fosse dado a bancos, como o Goldman Sachs, a fim de evitar a falência deles.

É importante ressaltar que o detetive é uma figura que investiga o crime para além das autoridades, por fora da instituição policial. No caso do filme, que coloca o conceito de "crime" em outra perspectiva, isso é de extrema relevância, uma vez que as relações de interesse entre Capital e Estado colocam o próprio aparato jurídico oficial na posição de criminoso, fazendo surgir a necessidade de uma espécie de "justiça paralela".

Em geral, o detetive é um agente que investiga o crime a serviço da vítima, mas está acima (ou fora) do processo. Aqui, no entanto, nosso detetive tem como motivação investigar um crime do qual ele também é vítima e testemunha. E, exatamente por fazer parte desse processo, em alguns momentos ultrapassa a linha que separa o detetive - cuja função termina no desvendamento do processo - do herói, que pretende fazer justiça com as próprias mãos, buscando uma alternativa para resolver a situação, uma vez que os responsáveis pelo crime são intocáveis pela lei, devido a seu poder político e econômico.

Mais do que um detetive que investiga o crime e o explica, o personagem-herói de Capitalismo: uma história de amor apresenta a necessidade de construir uma nova ordem, reverter as regras do jogo, pelas quais é impossível alcançar a justiça. O exemplo mais evidente é a sequência em que o personagem ${ }^{6}$ Michael Moore decide ir aos bancos para recolher os US\$170 bilhões que estes receberam do governo durante

\footnotetext{
${ }^{6}$ São três as instâncias de "Michael Moore" nessa narrativa fílmica: o personagem, o narrador e o cineasta. É importante ressaltar que existe um personagem fictício criado na narrativa e que se distingue do cineasta. É a este personagem que nos referimos aqui.
} 
a crise. Vejamos um dos vários diálogos que aparecem na montagem, no qual ele conversa com o segurança do escritório central do Goldman Sachs em Wall Street, em frente à porta giratória do banco:

Moore: Viemos para recuperar o dinheiro dos americanos.

Segurança: Entendo, senhor. Mas você não pode entrar.

Moore: Você pode pegar o saco? [Oferece ao segurança uma sacola com um cifrão desenhado.]

Segurança: Não.

Moore: Levá-lo lá para cima, enchê-lo?

Segurança: De maneira alguma.

Moore: Tenho mais sacos. Talvez \$1o bilhões não caibam aqui. [Olha para o saco, conferindo o tamanho]

[corte]

Moore: Você não pode nos ajudar a recuperar o dinheiro?

Segurança: Não posso.

Moore: O que aconteceria se eu tentasse entrar à força?

Segurança: [Não responde verbalmente, apenas gesticula algo como "não é óbvio?"] (CAPITALISMO, 2010).

O personagem heroico criado aqui beira o ridículo, e a tentativa de entrar num banco para pegar devolta o dinheiro, após um diálogoamistoso com o segurança em frente à porta giratória, revela ainda mais o absurdo dessa interação proposta por Moore. Ao mesmo tempo, entretanto, é por meio desse humor quase pastelão que o espectador é levado a refletir sobre o absurdo da situação que a originou (a ajuda financeira dada aos bancos que foram os grandes responsáveis pela crise, enquanto grande parte da população foi expulsa de suas casas, sem receber qualquer ajuda do governo). O herói, nessa cena, isoladamente, é visto como um ladrão de banco, mas, quando a juntamos com a estrutura argumentativa do filme, concluímos que a lógica está invertida, e os verdadeiros criminosos dessa história na verdade são os banqueiros. A mensagem, portanto, é a de que tirar o dinheiro deles seria a coisa mais sensata a fazer.

Esse diálogo também deixa evidente que o cineasta criou um personagem faux-naïf para problematizar a ideia do indivíduo-herói que recorre a pequenas ações civis e faz justiça com suas próprias mãos para resolver os problemas da nação, conceito amplamente difundido pela indústria cultural norte-americana. 
A crítica do filme ao conceito de herói está em toda essa sequência. A combinação de planos de arranha-céus filmados em contra-plongée, ${ }^{7}$ do carro-forte, dos closes do personagem dando partida no carro, de seu pé acelerando e de sua mão trocando a marcha, além de elementos como a chuva e a alta velocidade, cria uma paródia dos filmes hollywoodianos que fazem parte de nosso repertório cultural.

Na última cena do filme, o personagem Michael Moore vai para Wall Street - a cena do grande crime, o Capital Financeiro - marcar o local e fazer mais uma tentativa de aprisionamento dos culpados. Nesse momento, os limites da possibilidade de ação individual do herói, que já podiam ser observados na sequência anterior, são explicitados pelo comentário final, feito pelo narrador em voz-over: "Quer saber? Já não posso mais fazer isso sozinho. A menos que vocês, que estão me assistindo, queiram se juntar a mim. Espero que sim. E, por favor, apressem-se" (CAPITALISMO, 2010). Assim, o filme ao mesmo tempo constrói e desconstrói a figura tradicional do herói, propondo ao final uma espécie de herói-coletivo, que poderíamos chamar de "sujeito histórico".

O convite do narrador para que nos juntemos a esse processo político de transformação social coloca o espectador na posição não apenas de testemunha, mas também de sujeito histórico. Resta nos perguntarmos se a estrutura formal do filme nos permite experienciar também o papel de detetive, ou seja, se o didatismo de Moore funciona como mera exposição de uma tese que devemos apenas aceitar passivamente (como um roteiro simplista de uma história de detetive, que esconde do leitor informações e as revela como um produto final a ser consumido de maneira fetichizada), ou se ele consegue criar uma relação mais profunda com o espectador, dando a ele um papel ativo na interpretação dos elementos e na construção da tese.

É aqui que precisamos dar continuidade à nossa investigação do conceito de cinema-ensaio, para podermos entender os parâmetros formais por meio dos quais o filme de Moore é construído, e as consequências disso na relação que ele consegue estabelecer com os espectadores.

O cinema-ensaio é comumente descrito como uma forma que mescla documentário e reflexão pessoal, explorando, por meio de uma

7 Tipo de enquadramento audiovisual em que a câmera filma o objeto de baixo para cima, engrandecendo a imagem e sugerindo sua imponência. 
perspectiva cinematográfica, a subjetividade da tradição ensaística fundada por Montaigne. Ao contrário do padrão clássico de documentário expositivo (NICHOLS, 2005), que propõe clareza, objetividade e não intervenção, o filme ensaístico possui uma subjetividade mediadora explícita, que muitas vezes questiona a si mesma ao longo do filme, tornando-se autorreflexiva, e fazendo uma análise das ilusões de neutralidade da imagem. Essa presença autoral pode ou não ocorrer por meio da autobiografia. Nas palavras de Corrigan (2011, p. 30):

\begin{abstract}
Uma subjetividade expressiva, comumente vista na voz ou na presença do próprio cineasta, tornou-se um dos traços mais definidores do cinema-ensaio, algumas vezes marcadamente visível, outras vezes não. Assim como a primeira pessoa no ensaio literário surge para marcar uma voz e perspectiva pessoal, os filmes ensaísticos costumam enfatizar uma persona real ou fictícia, cujas jornadas e questionamentos definem e direcionam o filme a uma narrativa tradicional e frequentemente complicam o olhar documental do filme com a presença de uma subjetividade pronunciada ou de uma posição anunciada.
\end{abstract}

Capitalismo: uma história de amor, assim como toda a obra de Moore, possui claramente os traços de subjetividade característicos do cinemaensaio. Apesar de haver a exposição de uma tese, esta nos é apresentada a partir de uma história que possui a perspectiva do personagem/narrador/ diretor, que desde o início se coloca no centro dos acontecimentos.

Um dos elementos mais evidentes do estilo de Moore é o fato de ele se colocar na contramão da proposta de "não intervenção" do cinema documentário tradicional. O uso recorrente devoz-over, de montagem, de cortes abruptos (que não permitem continuidade espaço-temporal, nem plano-sequência ou profundidade de campo), de música externa à cena, de entrevistas, de comentários e de intervenções dos mais variados tipos (desde o uso de zoom para enfatizar algo específico no enquadramento, até a aparição literal do cineasta em cena) nos evidenciam que a estética desse filme também não pode de forma alguma ser classificada como pertencente ao "modo observacional" (NICHOLS, 2005).

Sabendo que o modo observacional é a filosofia do Cinema-Direto, e que essa estética foi amplamente utilizada nos documentários dos anos 1950 e 1960 nos Estados Unidos, poderíamos até mesmo refletir sobre uma provável intenção do cineasta em negar esse estilo propositalmente, como um argumento político de que é preciso, sim, intervir. A visão de que o cineasta não deve se posicionar, de que é possível captar uma realidade de um mundo autêntico - a vida como ela é - assemelha-se ao discurso de "objetividade" do jornalismo, o qual Capitalismo: uma história de 
amor claramente questiona. Assim, o filme não apenas recusa a ideia de um diretor invisível, como faz questão de mostrar sua visibilidade, intervenção e posicionamento político do início ao fim, seja por meio de sua voz, seja por meio de sua aparição física.

A aparição física de Moore como um personagem de seu próprio filme é um dos principais elementos que trazem um tom subjetivo e autobiográfico para a narrativa. O documentarista não é uma entidade invisível atrás da câmera, já que traz para o filme seus próprios questionamentos e, muitas vezes, torna-se o próprio assunto do filme que faz. Por exemplo, logo após uma sequência que investiga o conceito de "capitalismo", por meio de uma montagem com material de arquivo (um vídeo educacional de 1948 sobre o tema), inicia-se uma cena em que vemos uma seleção de vídeos caseiros e fotografias da infância de Michael Moore, ao mesmo tempo em que ouvimos a seguinte narração do próprio diretor em voz-over: ${ }^{8}$

\begin{abstract}
Meu pai, um operário da linha de montagem da General Motors, comprou e pagou nossa casa antes que eu terminasse o jardim da infância. Trocávamos de carro a cada três anos. Íamos a Nova Iorque a cada dois anos. Esse sou eu em Wall Street. E ali estou eu dirigindo meu primeiro filme na Feira Mundial. Íamos a escolas católicas, vivíamos bem. Se isto era o capitalismo, eu adorava... assim como todo mundo (CAPITALISMO, 2010).
\end{abstract}

Esse fragmento biográfico do cineasta funciona, primeiramente, como uma forma de aproximar sua tese do espectador, por meio de uma construção narrativa subjetiva que evoca impacto emocional e consequente identificação com o cineasta-protagonista. $\mathrm{O}$ diretor deixa seu ponto de vista extremamente marcado; se ainda não o tivéssemos percebido em momentos anteriores no filme, aqui temos certeza do lugar de onde ele fala e a qual grupo social ele pertence: o da classe trabalhadora, principal vítima das contradições do sistema capitalista e da consequente crise financeira do século XXI.

Nascido em 1954 nos Estados Unidos, Moore viveu sua infância num clima ideológico que majoritariamente via o sistema econômico capitalista como sinônimo de progresso e bem-estar social para todos, inclusive para a classe trabalhadora. Descreve, em sua narração, que sua vida tinha certo conforto e que por isso ele, e todo i seu grupo social,

${ }^{8}$ Recurso frequentemente utilizado em documentários, por meio do qual a voz do narrador descreve os fatos de fora da cena. É uma espécie de narrador onisciente. 
aceitavam as condições do sistema, que parecia lhes trazer benefícios suficientes.

Quando Moore coloca sua perspectiva enquanto criança em cena, o efeito não é apenas o de identificação público-protagonista, mas essencialmente a reflexão de que seu pensamento e sentimento em relação ao sistema econômico representam o espírito da década de 1950 nos EUA. Temos aqui uma reflexão a respeito do nível de consciência da classe trabalhadora americana naquele momento histórico, determinado em parte pelos benefícios que essa classe adquira, com políticas como o New Deal, e em parte por conta da imposição ideológica intensificada na época do macarthismo, como o material de arquivo usado na sequência anterior demonstra. O fato de Moore representar-se como criança nesse trecho do filme pode até mesmo ser lido como um simbolismo da ingenuidade e imaturidade de sua classe - vítima do discurso da classe dominante, na visão do cineasta. A música que escutamos na cena reforça essa ideia: a trilha sonora de A trapaça [Il bidone], filme dirigido por Fellini em 1955 e cujo enredo conta a história de três vigaristas que se aproveitam da ingenuidade de um povoado para lhes aplicar golpes.

O uso da experiência pessoal do cineasta faz com que nos envolvamos em sua representação do mundo histórico, mas "[...] de maneira indireta, por intermédio da carga afetiva aplicada ao filme e que o cineasta procura tornar nossa" (NICHOLS, 2005, p. 171). Além disso, se supusermos que o público-alvo de Capitalismo: uma história de amor é a classe trabalhadora americana, perceberemos que o filme rompe com o paradigma da tradição do documentário - a lógica do "nós falamos sobre eles para nós" - a favor da lógica do "nós falamos sobre nós para nós" (p. 172). Moore, como a caracterização física de seu personagem (obeso, de boné, jeans e tênis) reforça, é um membro da classe trabalhadora americana, discutindo sobre sua própria classe e cultura, com o intuito de comunicar-se com seu grupo social. Essa lógica difere de grande parte das produções documentais, nas quais temos um "eu" falando sobre um "outro" - esse "eu” geralmente é um intelectual que não possui relação de proximidade com o assunto e com as pessoas que retrata em seu filme.

O mesmo podemos observar na cena em que o cineasta-protagonista leva seu pai, antigo operário da General Motors, para visitar as ruínas da antiga fábrica responsável por grande parte da economia da sua cidade natal (Flint, Michigan). Nesse trecho, ouvimos uma conversa entre pai e filho, na qual os dois relembram momentos em que o filho ia buscar 
o pai no final do expediente, ou falam sobre o que o pai mais gostava em seu trabalho, enquanto vemos imagens de um enorme terreno vazio. Todos os momentos relembrados pelos dois são apenas narrados, e há um contraste entre a fala saudosista e a imagem de destruição e ausência. Por meio desse contraste, e novamente de uma história pessoal, os espectadores têm acesso à subjetividade de sua classe social em duas gerações e momentos históricos distintos. Nas palavras de Nichols (2005, p. 171), documentários desse tipo

[...] tentam representar uma subjetividade social que une o geral ao
particular, o individual ao coletivo, e o político ao pessoal. A dimensão
expressiva pode estar ancorada em indivíduos específicos, mas estende-se
para abarcar uma forma de reação subjetiva social ou compartilhada.

Num momento histórico em que existe dificuldade de figuração do conceito de luta de classes, o "pessoal" serve de ponto de partida para a entrada no "político" por meio da experiência (os 33 anos de trabalho do pai na fábrica) e da memória (compartilhando, por intermédio da narrativa, fragmentos do passado que dão significação ao presente). "Experiência e memória, envolvimento emocional, questões de valor e crença, compromisso e princípio, tudo isso faz parte de nossa compreensão dos aspectos do mundo" (NICHOLS, 2005, p. 178).

Nas palavras de Corrigan (2011, p. 13), “desde suas origens literárias até suas revisões cinematográficas, o processo ensaístico descreve as várias camadas do ponto de vista pessoal enquanto uma experiência pública". ${ }^{9}$ Ainda segundo o autor, o mais interessante do ensaio não é o fato de ele privilegiar uma expressão pessoal, uma subjetividade, mas sim o fato de ele problematizar a própria noção de expressividade e sua relação com a experiência, as tentativas de articulação de um eu interior com o mundo exterior.

A construção da subjetividade do protagonista Michael Moore em Capitalismo: uma história de amor - assim como em toda a sua filmografia - acaba por estabelecer uma "estrutura de sentimento" (WILLIAMS, 1977) de seu tempo histórico. Mais do que isso, sua forma de narrar revela as contradições e os limites ideológicos dessa subjetividade, ao colocar-se como fruto desse processo. É na relação do sujeito com seu cotidiano, nas experiências que surgem a partir das relações sociais das quais faz parte,

9 "[...] from its literary origins to its cinematic revisions, the essayistic describes the manylayered activities of a personal point of view as a public experience". 
que se constrói sua identidade. Segundo Adorno (2003, p. 26), em seu texto "O ensaio como forma", "a experiência meramente individual, que a consciência toma como ponto de partida por sua proximidade, é ela mesma já mediada pela experiência mais abrangente da humanidade histórica”. Em outras palavras, a subjetividade deve ser vista como algo condicionado historicamente.

Não podemos deixar de observar aqui outro elemento essencial da forma ensaística, que vem da própria origem do termo, essayer. O ensaio é uma tentativa, um exercício de acertos e erros, uma investigação que utiliza várias abordagens, ângulos e interações. A mistura de elementos da ficção, da autobiografia e do documentário expositivo é um dos possíveis métodos que, ao longo de sua história, o cinema encontrou para expressar-se de maneira ensaística.

Dessa maneira, o ensaio pode ser visto como um método dialético, com continuidades e descontinuidades, revelando um processo de permanente mudança. Esse método está na contramão do pensamento positivista, no qual a estrutura textual se separa do conteúdo, havendo um descolamento entre o objeto e sua exposição. Tudo deve caber numa forma que precede o objeto. Nas palavras de Adorno (2003, p. 18), "para o instinto do purismo científico, qualquer impulso expressivo presente na exposição ameaça uma objetividade que supostamente afloraria após a eliminação do sujeito".

Ao contrário desse estilo cientificista, no qual os documentários tradicionais se espelham, o filme-ensaio estabelece uma relação com o objeto na qual este último é quem dita a forma de sua abordagem e exposição, sem que haja uma obrigação de pré-definir os conceitos.

Como já observado anteriormente, Capitalismo: uma história de amor utiliza a ideia de investigação não apenas como ponto de partida temático, mas também como forma. Uma sequência que evidencia esse processo formal ocorre no momento em que o filme desconstrói o discurso do ex-presidente George W. Bush (proferido durante a crise financeira de 2008 no Manhattan Institute), que afirma que "o capitalismo é o melhor sistema já criado". Em seguida, a voz-over do diretor acrescenta um comentário questionador: "Verdade?".

A construção argumentativa da sequência continua com dois trechos do discurso de Bush, intercalados por dois trechos de reportagens jornalísticas que funcionam como evidências para o contra-argumento de Moore: 
Bush: $O$ capitalismo oferece às pessoas a liberdade de escolher onde trabalhar, o que fazer...

Jornalista em voz-over: Pat Andrews procura por emprego. Todas as manhãs, ela lê em vão os classificados. [vemos imagens de uma senhora idosa lendo jornal]

Pat Andrews: Não há nada aqui. Eu não serei dançarina de clube masculino.

Bush: [...] a oportunidade de comprar ou vender os produtos que querem.

Jornalista em voz-over: Tom Rendom tem evitado demissões na sua empresa de placas em Stockton, Califórnia, tudo por causa desta expressão que agora representa metade de seu negócio. [imagens de Rendom em sua loja vendendo uma placa onde lemos "foreclosure" [execução de hipoteca], e depois colocando a mesma placa em frente a uma casa]

Depois de usar pequenos trechos de relatos jornalísticos para contradizer as opiniões de Bush sobre a liberdade de escolha do capitalismo, o filme continua sua contra-argumentação com comentários e imagens feitas pelo próprio diretor a partir do argumento de Bush de que "se buscam justiça social e dignidade humana, o sistema de livre mercado é a solução”. Em seguida, a voz-over de Moore nos apresenta a história de um reformatório de jovens em Wilkes-Barre, na Pensilvânia, que foi privatizado e controlado pela empresa P. A. Child Care. Enquanto vemos imagens do reformatório, fotografias dos juízes e donos da empresa, além de trechos de entrevistas com alguns dos jovens condenados, Moore explicita seu contra-argumento, citando nomes e números como evidência, e entrevistando alguns dos jovens que foram injustamente condenados. Em seguida, apresenta sua conclusão sobre o caso: "Mas isso faz sentido, pois toda vez que o governo atribui a uma empresa com fim lucrativo as obrigações que ele deveria executar, o que vocês esperam que aconteça?”.

Após concluir que "tempo é dinheiro, muito dinheiro" e que "o capitalismo derrotou a democracia”, o passo seguinte da argumentação surge a partir da fala de Matt, um dos jovens que foram presos:

Matt: Tudo isso me fez sentir como um objeto que eles usaram para obter dinheiro e depois jogaram fora. Estou tentando melhorar meu voo. Tentando me preparar para o futuro, e deixar tudo isso pra trás. Durante o julgamento, não tive o mínimo controle, mas com o voo, sou apenas eu. Tenho que fazer tudo sozinho. Sou o único no controle. 
Moore (em voz-over): Matt adora voar e espera um dia ser piloto. Se ele conseguir, terá a segunda lição sobre o capitalismo: que nos EUA, às vezes é melhor trabalhar no Mc Donald's.

Esse trecho é seguido por cenas em que Moore utiliza evidências (entrevistas, imagens, trechos de programas jornalísticos, números e relatos de acidentes aéreos) que servem para argumentar sobre as condições precárias de trabalho dos pilotos de avião nos EUA nos últimos anos. A seguir, o diretor aproveita a menção do acidente aéreo - que matou diversos passageiros e os pilotos, que estavam sem condições de pilotar por conta do excesso de trabalho - para fazer a ligação com seu próximo argumento e a nova etapa de sua investigação, também em vozover: "Como essas empresas conseguem sair ilesas? Creio que isto seja o cerne do capitalismo: ele permite que saiamos impunes de qualquer coisa, como lucrar com a morte de um empregado".

Vemos, então, a história de pessoas que morreram e cujos empregadores (Amegy Bank e Walmart) haviam feito apólices de seguro - Dead Peasants Insurance - que dariam à empresa enormes quantidades de dinheiro com a morte do funcionário, funcionando como uma nova forma de investimento da empresa.

O argumento nessa cena é construído a partir da voz-over de Moore, ao dizer que "não entendia como isso podia ser legal. Afinal, há uma razão para existir uma lei me proibindo de fazer um seguro contra incêndio de sua casa, pois eu tenho interesse que ela seja incendiada”. Além disso, ouvimos as opiniões de um advogado especialista no assunto, imagens de trechos dos documentos das apólices e falas como as da filha de uma funcionária do Walmart recém-falecida: "Quando alguém morre, ninguém deveria lucrar com isso".

Toda a sequência acima descrita revela uma construção de roteiro que se assemelha a um processo de investigação, e não apenas de exposição da tese. Se Bush, em seu discurso sobre os benefícios do capitalismo, apresenta uma tese abstrata, o filme de Moore investiga cada um desses argumentos num plano mais concreto, ou seja, no cotidiano da população norte-americana. A desconstrução da tese de Bush é feita a partir de exemplos de indivíduos e grupos de indivíduos que mostram a crueldade do sistema; não em estatísticas, mas sim em histórias humanas.

O elemento de argumento e contra-argumento criado durante toda essa sequência também nos remete a um processo de escrita ensaística, que, segundo Corrigan (2011, p. 35), "é moldada pelo formato de 
pergunta-resposta-pergunta que vem da tradição do diálogo socrático, referindo-se diretamente a uma segunda pessoa como interlocutora”.

Outro ponto importante a ser observado na análise dessa sequência é em relação ao movimento de transição que a montagem faz da história do reformatório juvenil para a história da precariedade financeira dos pilotos. Tal movimento é interessante exatamente por criar uma sensação de aleatoriedade do processo ensaístico. A partir de um elemento-"surpresa" que surge durante a entrevista com o adolescente Matt, o filme parte para uma nova fase de investigação, que trará um novo contra-argumento para rebater a tese pró-capitalista de Bush.

A aleatoriedade discursiva, além disso, serve para corroborar com a tese do filme de que os problemas vividos no cotidiano da população são sistêmicos, e não exceções à regra. A sensação que essa sequência gera é a de que, não importando para que lado a investigação vá, sempre encontraremos um exemplo de crueldade do sistema capitalista. Os diversos exemplos coletados durante a investigação dessa construção discursiva formam uma constelação, na qual os elementos parecem ser independentes uns dos outros, mas na verdade fazem parte de uma rede.

As entrevistas em si também possuem momentos investigativos e de aprendizado, com tentativas de estabelecer conexões entre os fragmentos coletados até então. Esse é o caso da relação que o filme estabelece entre a entrevista com o advogado especialista na apólice de seguro Dead Peasants e a entrevista com a viúva do funcionário que morreu. É interessante notar que, por meio da montagem intercalada dessas duas entrevistas, cria-se a sensação de que o personagem Michael Moore, ao conhecer o caso individual desse funcionário, procura um especialista para se informar e compreender o processo de maneira mais abrangente. E que, em seguida, ele leva as informações coletadas em seu contato com o advogado para a viúva, funcionando como uma espécie de ponte capaz de compartilhar o conhecimento intelectual e a vivência cotidiana.

Em linhas gerais, poderíamos dizer que a investigação feita pelo personagem Michael Moore durante a narrativa - organizada pelo narrador e autor-implícito - percorre dois caminhos. O primeiro, que traz elementos de um documentário mais tradicional, funciona como um texto científico argumentativo, com teses, argumentos e evidências, e reflete uma vontade de organizar e sistematizar as informações de maneira didática. O segundo caminho, que se mistura ao primeiro, é uma 
tentativa de recolher fragmentos encontrados por uma subjetividade que divaga em meio à própria dificuldade de compreensão do processo histórico no qual está inserida. Esse segundo caminho pode ser visto como ensaístico porque os conceitos que surgem nele “[...] só se tornam mais precisos por meio das relações que engendram entre si" (ADORNO, 2003, p. 28). De acordo com Corrigan (2011, p. 31),

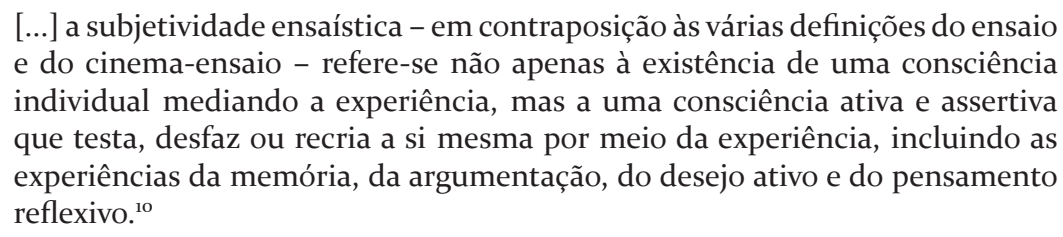

Esse pensamento autorreflexivo - subjetividade mediadora explícita que se questiona ao longo da narrativa - é o último elemento que nos falta investigar a respeito das relações entre o filme de Moore e a forma ensaística. Afinal, o filme ensaístico é "uma forma que pensa" [a form that think] (GODARD apud CORRIGAN, 2011, p. 33).

Grande parte da reflexão do filme de Moore está focada em discutir o papel da representação imagética no embate político. Logo na abertura do filme, vemos uma montagem com diversas imagens de câmeras de vigilância captando roubos a bancos. A tese dessa cena nos parece ser a de que os roubos pequenos são registrados pelas câmeras, mas os grandes (como o pacote de ajuda financeira, ou mesmo o sistema capitalista em si) não são registrados. As câmeras de vigilância, assim como a grande mídia, estão a serviço dos grupos hegemônicos, e servem para proteger a propriedade privada, e não para questionar e colocar em risco o status quo. Já a câmera do cinema político de Moore, como ele parece defender no filme, conseguirá ir além desses pequenos roubos, e nos mostrará o que a grande mídia nunca mostrou.

Outro momento questionador acontece numa das últimas cenas do filme, quando vemos um helicóptero sobrevoando a região de New Orleans afetada pela enchente do furacão Katrina. A câmera, filmando da perspectiva do helicóptero, aproxima-se das pessoas que estão

\footnotetext{
10 "[...] essayistic subjectivity - in contradistinction to many definitions of the essay and essay film - refers then not simply to the emplacement or positioning of an individual consciousness before and in experience but to an active and assertive consciousness that tests, undoes, or re-creates itself through experience, including the experiences of memory, argument, active desire, and reflective thinking".
} 
procurando ajuda, em cima de seus telhados, para filmá-las e depois se afastar delas. Durante essa exibição da filmagem, escutamos Moore em voz-over:

\begin{abstract}
Moore: Lembro-me de pensar, durante a enchente do Katrina: por que são sempre os pobres que sofrem com desgraças? Por que não é o Bernie Madoff que está no telhado gritando socorro? Ou o presidente do Citibank? [...] Nunca são eles, né? São sempre aqueles que nunca receberam um pedaço do bolo, porque esses homens levaram tudo, deixando-os sem nada, deixando-os para morrer (CAPITALISMO, 2010).
\end{abstract}

Enquanto ouvimos a última frase desse comentário, a câmera se afasta cada vez mais das vítimas, até enquadrar uma visão panorâmica da enchente e ir embora de vez, numa transição lenta para a cena seguinte por meio de um fade-out." Quando juntamos comentário e imagem, percebemos uma crítica não só aos banqueiros e acionistas, mas também à grande mídia e à própria estética do documentário observacional, cujas câmeras têm a função de se aproximar dos problemas sociais apenas como objetivo de explorar a imagem das vítimas, mas nunca de investigar as causas, questionar o sistema e principalmente intervir para tentar resolvê-lo. "Eu me recuso a viver num país como esse. E não vou sair daqui”, são as palavras de Moore em voz-over, que nos levam para a última cena do filme, na qual ele tenta sua última intervenção. Essas duas cenas entram em oposição e nos revelam o que Moore defende como seu projeto de contracultura: revelar o que a grande mídia não revela, além de intervir e fazer parte da luta contra o sistema capitalista. Isso se evidencia nas últimas palavras de seu discurso final:

\begin{abstract}
Moore: Merecemos o sonho de Roosevelt. E é um crime não termos isso. E nunca teremos, enquanto tivermos um sistema que enriquece poucos às custas de muitos. O capitalismo é um mal, e não se pode regular o mal. Temos de eliminá-lo, e substituí-lo por algo que seja bom para todos. E esse algo se chama democracia.
\end{abstract}

Se esse filme faz uma crítica ao modo como se representa a realidade, essa crítica está concentrada nos outros (a grande mídia, os modelos tradicionais de documentário), mas não em seu próprio filme. Existe uma reflexão sobre o fazer fílmico como um todo, mas não uma autorreflexão. $\mathrm{O}$ filme de Moore, nesse aspecto, se assemelharia às produções que "fazem

${ }^{11}$ Técnica audiovisual que cria um efeito de escurecimento, por meio do desaparecimento gradativo da imagem no final de uma cena. 
metacomentários sobre métodos e procedimentos ao mesmo tempo em que permanecem dentro de uma sensibilidade realista" (NICHOLS, 2005, p. 70). Assim, se Moore mostra em muitos momentos o discurso hegemônico como fabricado, em geral não faz o mesmo com seu próprio discurso. Quando expõe sua tese, as técnicas utilizadas são próximas ao modo expositivo e há uma "suspensão da descrença" (RUBY, 1988), na qual o espectador volta a cair na ilusão do filme como representação fiel da realidade.

Nesse caso, precisamos pensar na função que se estabelece quando se rompe o coeficiente de ilusão num filme. Existem dois caminhos: o cineasta o faz para refletir sobre o processo e levar o espectador a uma reflexão pessoal; ou para explorar os processos sociais mascarados. De uma maneira formal, a reflexão desvia nossa atenção para nossas suposições e expectativas sobre a forma do documentário em si. De uma perspectiva política, a reflexão aponta para nossas suposições e expectativas sobre o mundo que nos cerca. Ambas se baseiam em técnicas que nos chocam, que alcançam algo semelhante ao que Bertolt Brecht descreve como "efeitos alienantes", ou ao que os formalistas russos denominam de "estranhamento".

No caso do filme de Moore, vemos que a discussão central não é o processo fílmico (reflexão formal), mas sim o processo social (reflexão política). Assim, poderíamos considerar certos momentos do filme de Moore como politicamente reflexivos, uma vez que "eles apontam para nós, espectadores e atores sociais, e não para os filmes, como agentes que podem fechar essa brecha entre aquilo que existe e as novas formas que desejamos para isso que existe" (NICHOLS, 2005, p. 168).

Bazin (1991, p. 67), ao discutir o papel da montagem no cinema, percebe duas tendências opostas na tradição dos anos 1920 aos 1940, as quais poderíamos transpor para uma análise do cinema contemporâneo: "os diretores que acreditam na imagem e os que acreditam na realidade". Eisenstein seria o grande exemplo deste segundo grupo, o da "realidade", e sua montagem seria "o reforço do sentido de uma imagem pela aproximação de outra imagem que não pertence necessariamente ao mesmo acontecimento" (BAZIN, 1991, p. 67). Para Bazin, o problema desse tipo de montagem é o fato de ela criar "um sentido que as imagens não contêm objetivamente e que procede unicamente de suas relações" (p. 68). Dessa forma, o cineasta controla a interpretação da mensagem, impondo aos espectadores sua visão do acontecimento representado. $\mathrm{O}$ 
autor opõe o recurso da montagem de Eisenstein ao uso da profundidade de campo e do plano-sequência, que permitiriam certa ambiguidade e deixariam o espectador mais livre para fazer suas próprias associações.

Se pensarmos nessas duas tradições, Capitalismo: uma história de amor se aproximará muito mais da tendência de Eisenstein. Existe certo didatismo na linguagem de Moore que, na leitura de Bazin, pode ser lido como manipulação ideológica. Precisamos, porém, analisar esse filme sob a ótica da tradição marxista (da qual tanto Moore quanto Eisenstein fazem parte) e seu conceito de ideologia como "falsa experiência social". Se a falsa experiência, segundo o marxismo, mascara a verdade, caberia à produção cultural engajada o papel principal de desmascaramento do processo que nos leva a essa falsa experiência, e não o papel central de refletir sobre seu próprio fazer fílmico, numa leitura do conceito mais amplo de ideologia como um conjunto de ideias e pensamentos. Assim, poderíamos concluir que o filme de Moore possui elementos de autorreflexão, mas que este não é o seu foco principal: para ele, é mais importante refletir sobre o mundo do que sobre o cinema que ele realiza.

Podemos ver a forma de Capitalismo: uma história de amor como síntese de um processo de investigação de um crime (uma usurpação que é econômica, mas também política e cultural) e da defesa que seu método artístico propõe, como tese de que a arte é capaz de revelar o processo histórico do qual sua subjetividade faz parte. Temos, assim, um exemplo do filme-ensaio como caminho para um discurso contra-hegemônico, um projeto cognitivo que tenta recuperar os meios de representação a serviço de um embate histórico.

\section{REFERÊNCIAS}

ADORNO, Theodor W. O ensaio como forma. In: Notas de literatura I. São Paulo: Editora 34, 2003, pp. 15-45.

BAZIN, André. A evolução da linguagem cinematográfica. In: $O$ cinema: ensaios. São Paulo: Brasiliense, 1991, pp. 62-78.

BRECHT, Bertolt. A ópera dos três vinténs. In: Teatro completo em 12 volumes, v. 3. São Paulo: Paz e Terra, 1991.

CAPITALISMO: UMA história de amor. Direção de Michael Moore. Estados Unidos, Paramount Pictures, 2009. Filme (127 minutos). DVD. Título original: Capitalism: A Love Story. 
O Cinema-Ensaio como forma no documentário Capitalismo: uma história de amor - 874

CORRIGAN, Timothy. The Essay Film: from Montaigne, after Marker. New York: Oxford University Press, 2011.

MOORE, Michael. My New Movie: Capitalism a Love Story (trailer). Huffington Post. 20 set. 2009. Disponível em: <http://www.huffingtonpost.com/michael-moore/trailermichael-moores-ca_b_264794.html>. Acesso em: 10 abr. 2017.

NICHOLS, Bill. Representing Reality: Issues and Concepts in Documentary. Bloomington: Indiana University Press, 1991.

NICHOLS, Bill. Introdução ao documentário. Campinas: Papirus, 2005.

RUBY, Jay. The Image Mirrored: Reflexivity and the Focumentary Film. In: ROSENTHAL, A. (org.). New Challenges for Documentary. Berkeley: University of California Press, 1988, pp. 34-41.

WILLIAMS, Raymond. Marxism and Literature. New York: Oxford University Press, 1977. 